\title{
Pengaruh Kinerja Lingkungan, Umur Perusahaan dan Proporsi Dewan Komisaris Independen pada Pengungkapan Informasi Lingkungan
}

\author{
Anak Agung Istri Pawitradewi ${ }^{1}$ \\ Fakultas Ekonomi dan Bisnis \\ Universitas Udayana, Indonesia \\ Email: awitradewi@gmail.com
}

\author{
Made Gede Wirakusuma² \\ Fakultas Ekonomi dan Bisnis \\ Universitas Udayana, Indonesia
}

\begin{abstract}
ABSTRAK
Penelitian ini bertujuan untuk mengetahui pengaruh kinerja lingkungan, umur perusahaan dan proporsi dewan komisaris independen pada pengungkapan informasi lingkungan. Sampel dari penelitian ini yaitu 24 perusahaann dimana sampel ini didapatkan melalui metode purposive sampling dengan kriteria yaitu perusahaann high profile yang terdaftar di BEI dan terdaftar menjadi peserta PROPER tahun 2016-2018. Pengolahan data penelitian dilakukan dengan menggunakan teknik analisis data regresi linier berganda. Hasil yang didapatkan setelah dilakukan pengujian adalah kinerja lingkungan dan proporsi dewan komisaris independen memiliki pengaruh positif pada pengungkapan informasi lingkungan. Sedangkan hasil penelitian yang ditemukan dari hubungan antara umur perusahaan pada pengungkapan informasi lingkungan adalah tidak ditemukan adanya pengaruh antara kedua variabel tersebut.
\end{abstract}

Kata Kunci: Kinerja Lingkungan; Umur Perusahaan; Proporsi Dewan Komisaris Independen; Pengungkapan Informasi Lingkungan.

\section{Effect of Environmental Performance, Company Age and Proportion of Independent Commissioners on Environmental Disclosure}

\section{ABSTRACT}

This study aims to determine the effect of environmental performance, company age and the proportion of independent commissioners on disclosure of environmental information. Samples from this study were 24 companies where this sample was obtained using a purposive sampling method with the criteria of high profile companies listed on the IDX and registered as participants in the 2016-2018 PROPER. Research data processing was performed using multiple linear regression data analysis techniques. The results obtained after testing are environmental performance and the proportion of independent commissioners has a positive influence on the disclosure of environmental information. While the results of the study found from the relationship between the age of the company on the disclosure of environmental information is found no influence between the two variables.

Keywords: Environmental Performance; Company Age; Proportioni of Independent Commissioners; Environmental Disclosure.

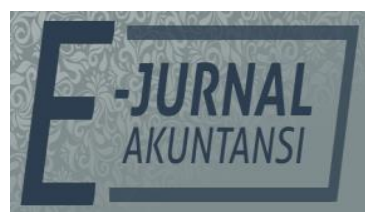

E-JA

e-Jurnal Akuntansi e-ISSN 2302-8556

Vol. 30 No. 3

Denpasar, Maret 2020

Hal. 598-610

Artikel Masuk:

23 November 2019

Tanggal Diterima: 15 Januari 2020 


\section{PENDAHULUAN}

Pengungkapan informasi lingkungan merupakan pengungkapan di dalam laporan tahunan yang memuat informasi mengenai kinerja lingkungan yang juga termasuk bentuk tanggung jawab perusahaan kepada stakeholder berkenaan dengan masalah lingkungan itu sendiri (Pertiwi et al., 2018). Definisi lain dari pengungkapan informasi lingkungan adalah pengungkapan ukuran dan jenis polusi secara spesifik (emisi gas dan limbah beracun, pencemaran minyak dan lain-lain) yang berguna bagi investor dalam mengestimasi arus kas di masa mendatang (Al-Tuwaijri et al., 2003). Permasalahan lingkungan hidup di Indonesia merupakan masalah yang penting dan multidimensional serta melibatkan banyak pemangku kepentingan. Peran dari pemerintah dan pemerhati lingkungan berdampak pada tata kelola industri dalam pengelolaan lingkungan agar tidak melakukan pencemaran lingkungan (Yuniarta, 2019).

Kinerja perusahaan tidak hanya tercermin pada kinerja keuangan yangi baik tetapi perusahaan juga diharapkan memiliki tata kelola yang baik (Yuniasih \& Wirakusuma, 2008). Implementasi tata kelola perusahaan yang baik (good corporate governance) merupakan keinginan perusahaan dalam meningkatkan kinerja perusahaan (Putri, 2016). Dalam ekonomi global, permasalahan lingkungan hidup saat ini menjadi topik penting berdasarkan kasusi pencemaran lingkungan yang menimbulkan gangguan pada kehidupan sosial umat manusia (Ijma \& Nina, 2018). Ekploitasi secara berlebihan yang dilakukan tanpa memerhatikan faktor kelestarian lingkungan dapat menyebabkan berkurangnya sumber keseimbangan alam serta dampak polusi yang besar. Salah satu penyebab kerusakan lingkungan adalah rendahnya minat perusahaan terhadap konversi lingkungan (Juhairiyah et al., 2018).

Dampak dari pengelolaan lingkungan yang buruk dapat terlihat dari kasus-kasus lingkungani hidup di Indonesia yang masih kerap terjadi dan semakin meningkat. Dilansir dari pemberitaan online tanggal 16 Mei 2019, penambangan batu bara dan industri PLTU batu bara memiliki dampak yang serius terhadap kerusakan lingkungan. Di Kepulauan Karimunjawa, tongkangtongkang yang berlabuh dan jangkar yang tersangkut membuat terumbu karang rusak dan hancur serta tumpahan bagian-bagian batu bara yang jatuh mencemari laut. Beralih ke Sanga-sanga kabupaten Kutai Kertanegara, rumah-rumah rusak, jalan utama amblas karena aktivitas pertambangan yang berdekatan dengan permukiman dan fasilitas umum. Persoalan mengenai lumpur Sidoarjo hingga kini mengakibatkan peningkatan jumlah pasien ISPA (Penyakit Infeksi Saluran Pernafasan Atas) yang mengkhawatirkan. Kasus-kasus lingkungan yang terjadi mencerminkan masih maraknya perusahaan yang kurang memberikani perhatiannya terhadap dampak lingkungan atas aktivitas industrinya.

Berdasarkan teori legitimasi perusahaan dianjurkan untuk meyakinkan bahwa aktivitas dan kinerjanya dapat diterima oleh masyarakat (Putra \& Wirakusuma, 2015). Teori stakeholder juga menyatakan bahwa semua stakeholder perusahaan memiliki hak atas segala informasi karena mereka akan memengaruhi dalam pengambilan keputusan perusahaan (Sawaka \& Putri, 2016). Pengungkapan informasi lingkungan perlu diungkapkan oleh perusahaan secara lengkap terutama perusahaan-perusahaan yang memiliki aktivitas 
industri rawan lingkungan sebagai bentuk pertanggungjawaban perusahaan kepada stakeholder.

Kinerja lingkungan merupakan salah satu faktor yang memengaruhi pengungkapan informasi lingkungan. Kinerja lingkungan merupakan suatu kinerja atasi kepeduliani dan tanggung jawab perusahaan dalam menjaga kelestarian lingkungan terutama yang berkaitan dengan kegiatan atau aktivitas perusahaan itu sendiri. Semakin penting stakeholder bagi perusahaan, semakin banyak upaya akan dilakukan oleh perusahaan untuk mengelola pengungkapan informasi lingkungan sebagai cara untuk menyampaikan kinerja lingkungan mereka (Ghani \& Rosdi, 2019). Kinerja lingkungan dapat diukur menggunakan Program Penilaian Peringkat Kinerja Perusahaan dalam Pengelolaan Lingkungani (PROPER). Penelitian yang dilakukan oleh Amelia \& Cahyati (2015), Fontana (2015), Putra dan Utami (2017) serta penelitian oleh Purnama (2018) ditemukan bahwa terdapat hubungan yang positif antara kinerja lingkungan pada pengungkapan informasi lingkungan.

Berikut merupakan hasil dari penilaian PROPER perusahaan di Indonesia periode 2016-2018. Datai tersaji pada Tabel 1.

Tabel 1. Penilaian PROPER Perusahaan di Indonesia Tahun 2016-2018

\begin{tabular}{llllll}
\hline Tahun & Hitami & Merahi & Birui & Hijau & Emas \\
\hline $2015-2016$ & 5 & 284 & 1422 & 172 & 12 \\
$2016-2017$ & 1 & 130 & 1486 & 150 & 19 \\
$2017-2018$ & 2 & 241 & 1454 & 155 & 20 \\
\hline
\end{tabular}

Sumber: Data Penelitian, 2019

Faktor berikutnya yang berpengaruh pada pengungkapan informasi lingkungan yaitu umuri perusahaan. Umur perusahaan adalah lamanya perusahaan beroperasi sejak berdiri hingga waktu yang tak terbatas. Umur perusahaan berkaitan erat dengan teori legitimasi (Dedi Putra \& Utami, 2017).

Proporsi dewani komisaris independen dalam suatu perusahaan cenderung dapat meningkatkan pengawasan terhadap pengungkapan informasii yang lebih transparan serta berkualitas termasuk didalamnya pengungkapan informasi lingkungan yang akan dilakukan perusahaan (Ningsih, 2017). Hasili penelitian yang diperoleh Juniartha \& Dewi (2017) dan penelitian oleh Wardani \& Haryani (2018) menyatakan proporsi dewan komisaris independen berpengaruh positif pada pengungkapan informasi lingkungan.

Penelitian ini merupakan replikasi dari penelitian-penelitian yang telah diteliti sebelumnya dengan tujuan dapati memberikani kontribusi terhadap perkembangani teori serta memperkuat sintesis bahwa kinerja lingkungan, umur perusahaan dan proporsi dewan komisaris independen merupakan faktor yang memengaruh pengungkapan informasi lingkungan. Penelitian ini memiliki perbedaan dengan penelitian sebelumnya dimana dalam penelitian menggunakan sampel perusahaan high profile yang terdaftar di BEI dan menjadi peserta PROPER pada tahun 2016-2018. Penelitian pada perusahaan high profile yang terdaftar di BEI dan menjadi peserta PROPER dilakukan karena perusahaan high-profile merupakan perusahaan dengan industri rawan lingkungan sehingga diyakini dapati memberikani informasii yang akurat dan andal dalam pengungkapan informasi lingkungan dan perusahaan peserta 
PROPER memiliki kecenderungan dalam mengungkapkan lebih luas kegiatan tanggung jawab lingkungan perusahaan.

Berdasarkan latar belakangi tersebut, maka peneliti termotivasi untuk melakukanipenelitian dengan judul "Pengaruh Kinerja Lingkungan, Umur Perusahaan, dan Proporsi Dewan Komisaris Independen pada Pengungkapan Informasi Lingkungan".

Legitimasi akan terbangun dengan baik apabila masyarakat dan perusahaan dapat bekerjasama dengan baik (Dowling dan Pfeffer, 1975). Legitimasii organisasi dapat dilihat sebagai sesuatu yang diberikan masyarakat kepada perusahaan dan sesuatu yang diinginkan atau dicari perusahaan dari masyarakat (O'Donovan, 2002). Menurut Brown et al., (1998) perusahaan akan diperoleh jika terdapat kesamaan antara hasil dengan yang diharapkan oleh masyarakat dari perusahaan, sehingga tidak ada tuntutan dari masyarakat. Pengungkapan informasi lingkungan perusahaan digunakan sebagai media penghubung antara perusahaan dengan masyarakat agar mendapatkan legitimasi atas pengungkapan yang telah dilakukan perusahaan (Aulia \& Agustina, 2015). Keinginan perusahaan untuk melegitimasi perusahaan mereka adalah salah satu motivasi utama perusahaan untuk melaporkan kegiatan ilingkungan yang dilakukannya (Cho \& Patten, 2007).

Teori stakeholder menyatakan bahwa perusahaan bukanlah entitas yang beroperasi untuk kepentingan sendiri namun harus memberikan manfaat bagi para stakeholdernya (Ghozali \& Chairi, 2016). Hak yang dimilik oleh semua stakeholder yaitu memperoleh informasi mengenai seluruh aktivitas perusahaan yang memengaruhi mereka (Dewi \& Yasa, 2017). Orlitzky et al., (2003) mengungkapkan bahwa kepuasaan stakeholder adalah sebuah investasi. Tujuan utama mengungkapkan informasi lingkungan adalah pengungkapan kebijakan yang mengesampingkan asimetri informasi serta menempatkan, jika perlu, tekanan pada perusahaan untuk mengurangi emisi (Wang et al., 2019).

Pengungkapan informasi lingkungan merupakan pengungkapan tanggung jawab lingkungan yang memuat informasi berkaitan dengan aktivitas perusahaan (Ahada et al., 2016). Untuk menciptakan lingkungan yang baik perusahaan memfokuskan aktivitasnya pada kegiatan perusahaan dalam melestarikan lingkungan dan mengurangi dampak lingkungan yang timbul akibat aktivitas perusahaan. Umur perusahaan berfungsi sebagai indikator stabilitas yang dirasakan perusahaan Hui (2012) dan mewakili beberapa aspek kekuatan pemangku kepentingan, postur strategis dan kinerja keuangan (Roberts, 1992). Umur perusahaan telah dianggap sebagai karakteristik perusahaan penting lainnya yang dapat mempengaruhi tingkat pengungkapan informasi lingkungan (Emre Akbas, 2014).

Dewan komisaris adalah wakil pemegang saham dalam perusahaan berbadani hukumi perseroani terbatas. Dewan komisaris memilik wewenang dalam mengawasi aktivitas yang dilakukan perusahaan sebaga wakil dari para shareholder. Dewan komisaris independen merupakan bagian dari corporate governance. Keberadaan komisaris independen telah tercantum dalam Bursa Efek Indonesia (BEI). Dalam peraturan tersebut dijelaskan bahwa perusahaan diharuskan memiliki proporsi dewan komisaris ndependen yang proporsional. Fama \& Jensen (1983) menyatakan dewan komisaris merupakan mekanisme 
pengendalian intern tertinggi yang bertanggungjawab untuk memonitor tindakan manajemen puncak.

Penelitiani mengenai hubungan antara kinerja lingkungan pada pengungkapan informas lingkungan telah dilakukan sebelumnya oleh Clarkson et al., (2008) , Fontana (2015), dan Purnama (2018). Hasil yang didapatkan dari penelitian tersebut yaitu kinerja lingkungan memiliki pengaruh positif pada pengungkapani informasi lingkungan.

$\mathrm{H}_{1}$ : Kinerja lingkungan berpengaruhi positif pada Pengungkapan Informasi Lingkungan.

Penelitiani terdahulu yang dilakukan oleh Ciriyani dan Putra (2016) menyatakan bahwa umur perusahaan berpengaruh pada pengungkapan informasi lingkungan. Hasil penelitian tersebut menunjukkan umur perusahaan memiliki hubungan yang positif pada pengungkapan informas lingkungan. Dengan demikian, apabila perusahaan semakin lama terdaftar dan bertahan pada Bursa Efek Indonesia, maka sebagai bentuk tanggung jawab kepada stakeholder dan keinginan perusahaan untuk menarik investor, maka perusahaan akan semakin banyak mengungkapkan informasi lingkungannya pada laporan tahunan yang mereka terbitkan. Berdasarkan penjabaran tersebut, maka dapat dirumuskan hipotesis sebagai berikut:

$\mathrm{H}_{2}$ : Umur Perusahaan berpengaruh positif pada Pengungkapan Informasi Lingkungan.

Beberapa penelitian menunjukkan adanya hubungan antara propors dewan komisaris independen pada pengungkapan informas lingkungan. Hasil penelitian oleh Juniartha \& Dewi (2017), Uwuigbe et al., (2011) dan Wardani \& Haryani (2018) menyatakan proporsi dewan komisaris independen memiliki pengaruh positif pada pengungkapan informasi lingkungan. Dengan demikian semakin besar propors dewan komisaris independen maka dapat meningkatkan pengawasan serta memberikan tekanan terhadap manajemen untuk melakukan pengungkapan informasi lingkungan. Berdasarkan penjabaran tersebut, maka dapat dirumuskan hipotesis sebagai berikut:

$\mathrm{H}_{3}$ : Proporsi Dewan Komisaris Independen berpengaruhi positif pada Pengungkapan Informasi Lingkungan.

\section{METODE PENELITIAN}

Penelitian ini menggunakan pendekatan kuantitatif. Penelitian ini menguji variabel kinerja lingkungan, umur perusahaan dan proporsi dewan komisaris independen pada pengungkapan informasi lingkungan. Lokasi penelitian yaitu pada perusahaan high profile yang terdaftar di Bursa Efek Indonesia (BEI) dan terdaftar menjadi peserta PROPER tahun 2016-2018.

Objek penelitian adalah suatu atributataus nilai dari orang objek atau kegiatan yang mempunyai variasi tertentui yang ditetapkan oleh peneliti untuk dipelajari dan ditarik kesimpulannya Sugiyono (2017:28). Dalam penelitian ini lingkup objek penelitian yaitu pengungkapan informasi lingkungan dalam laporan keberlanjutan (sustainability report) dan laporan tahunan (annual report).

Kinerja lingkungan adalah upaya-upaya perusahaan untuk menjaga kelestarian lingkungan terutama berkaitan dengan kegiatan atau aktivitas perusahaan itu sendiri. Kinerja perusahaan dalam pengelolaan ilingkungan 
diukur melalui PROPER yang diterbitkan oleh Kementrian Lingkungan Hidup (KLH). Peringkat kinerja lingkungan yang di dapat oleh masing - masing perusahaan dalam PROPER merupakan prestasi perusahaan dalam pengelolaan lingkungan. PROPER menggunakan warna-warna untuk menunjukkan peringkat perusahaan. Peringkat warna tersebut diantaranya emas, hijau, biru, merah dan hitam. Warna emas merupakan peringkat tertinggi berurutan dengan warnai lainnya yaitu hijau, biru, merah dan hitam.

Pengukuran variabel umur perusahaani BEI dengan formula:

Notasi umur perusahaan $=\left(\mathrm{t}-\mathrm{t}_{0}\right)$

$\mathrm{t}=$ tahun data dan

$\mathrm{t}_{0}=$ tahun perusahaan tercatat

Proporsi dewan komisaris independen dalam penelitian ini dihitung menggunakan rasio antara jumlah anggota dewan komisaris independen dibandingkan dengan total anggota dewan komisaris perusahaan, perhitungannya mengacu pada penelitan Purnama (2018) dengan menggunakan rumus sebagai berikut:

PDKI $=\frac{\boldsymbol{\Sigma} \text { Komisaris Independen }}{\Sigma \text { Dewan Komisaris }} \boldsymbol{x} \mathbf{1 0 0} \%$

Variabel ini diukur menggunakan skor pengungkapan informasi lingkungan pada laporan tahun perusahaan dengan indeks GRI.G4. Standar GRI dipilih karena lebih memfokuskan pada standar pengungkapan lingkungan, baik itu laporan keberlanjutan mandiri laporan terpadu laporan tahunan laporan yang membahas norma-norma internasional tertentu atau pelaporan online. (www.globalreporting.org).

Penggunaan indeks GRI dalam menghitung pengungkapan informasi lingkungan sesuai seperti penelitian yang dilakukan Ahada et al., (2016) yaitu dengan memberikan nilai 1 atas setiap pengungkapan yang sesuai dengan indeks 34 poin lingkungan GRI. Selanjutnya nilai tersebut dijumlahkan dan di bandingkan dengan total 34 poin pengungkapan informasi lingkungan GRI, cara penghitungannya:

PIL $=\frac{\text { Skor Pengungkapan Informasi Lingkungan Perusahaan }}{\text { Total Seluruh Pengungkapan Inf ormasi Lingkungan GRI (34 Poin) }} \boldsymbol{x} 100 \%$

Jenis data yang digunakan dalam penelitian ini adalah data kuantitatif. Data kuantitatif merupakan data yang berbentuk angka atau data kualitatif yang diangkakan (Sugiyono, 2017). Data kuantitatif penelitian ini adalah laporan tahunan (annual report) perusahaan high profile yang terdaftar di Bursa Efek Indonesia dan menjadi peserta PROPER periode 2016-2018.

Penelitian ini menggunakan data sekunder. Data sekunder merupakan data dimana pengumpul data mendapatkan data secara tidak langsung (Sugiyono, 2017). Sumber data sekunder dalam penelitian ini adalah dari IDX (Indonesian Stock Exchanges), website Kementrian Lingkungan Hidup www.menlh.go.id makalah buku.

Penelitian ini menggunakan perusahaan high profile yang terdaftar di BEI selama tahun 2016-2018. Menurut Anggraini (2006), industri yang termasuk dalam perusahaan berkategori high profile adalah industri dengan sektor industri energi, pertambangan, perkebunan, rokok, perikanan, kimia, semen, otomotif, kosmetik \& peralatan rumah tangga, makanan dan minuman, kertas, farmasi, 
dan plastik. Pemilihan perusahaan high profile yang terdaftar di BEI sebaga populasi, karena perusahaan yang termasuk dalam kategori high profile akan memberikan lebih banyak informas mengenai lingkungan.

Sampel adalah bagian dari jumlah karakteristik yang dimiliki oleh populasi tersebut (Sugiyono, 2017). Metode penentuan sampel dalam penelitian ini adalah menggunakan sampel nonprobabilitas (nonprobability sampling) dengan teknik purpose sampling. Adapun kriteria sampel dalam penelitian ini adalah sebagai berikut: Perusahaan high profile yang terdaftar di Bursa Efek Indonesia tahun 2016-2018. Perusahaan high profile yang menjadi peserta PROPER berturutturut selama tahun 2016-2018. Perusahaan high profile yang mempublikasikan sustainability report/annual report periode 2016-2018 dan dapat diakses melalui website www.idx.co.id.

Metode pengumpulan data yang digunakan dalam penelitian ini adalah metode observasi non partisipan yaitu metode pengumpulan data dengan cara mengamati mencatat serta mempelajari uraian-uraian dari buku-buku, karya ilmiah berupa skripsi dan artikel (Sugiyono, 2017).

\section{HASIL DAN PEMBAHASAN}

Populasi penelitian yang digunakan dalam penelitian ini adalah seluruh perusahaan high profile yang terdaftar di Bursa Efek Indonesia (BEI) selama tahun 2016-2018. Berdasarkan hasil pemilihan sampel dengan menggunakan metode purposive sampling, maka diperoleh jumlah perusahaan high profile yang terpilih sebaga sampel penelitian ini sebanyak 24 perusahaan. Proses seleks sampel disajikan pada Tabel 2. sebagai berikut :

Tabel 2. Proses Seleksi Sampel Penelitian

\begin{tabular}{lll}
\hline No & Kriteriai & $\begin{array}{l}\text { Jumlah } \\
\text { Perusahaan }\end{array}$ \\
\hline 1 & $\begin{array}{l}\text { Perusahaani High Profile yangi terdaftari dii Bursai Efeki } \\
\text { Indonesiai tahuni 2016-2018 }\end{array}$ & 155 \\
2 & $\begin{array}{l}\text { Perusahaani High Profile yangi terdaftari di iBursai Efeki } \\
\text { Indonesiai yangi tidaki mengikutii iPROPER selama tahuni }\end{array}$ & \\
& 2016-2018 & \\
3 & $\begin{array}{l}\text { Perusahaani High Profile yangi tidak ditemukan } \\
\text { sustainability report/annuali reporti secarai lengkapi selamai }\end{array}$ & \\
& tahuni 2016-2018 & \\
& Jumlah sampel perusahaan high profile & 24 \\
& Jumlahi pengamatani (24 xi 3 tahun)i & 72 \\
\hline
\end{tabular}

Sumber: Data Penelitian, 2019

Seleksi sampel penelitian diperoleh 72 data pengamatan yang memenuhi kriteria penelitian selama tahun 2016-2018. Jumlah ini diperoleh setelah perusahaan high profile yang terdaftar di BEI dan menjadi peserta PROPER pada tahun 2016-2018 sebanyak 27 perusahaan dikurangi dengan jumlah perusahaan high profile yang tidak ditemukan laporan keberlanjutan/laporan tahunan secarai berkalai sebanyaki 3 perusahaan, sehingga data yang digunakan dalam analisis sebanyak 72 data pengamatan.

Statistik deskriptif bertujuan untuk memberikan gambaran dan deskripsi tentang karakteristik masing-masingi variabeli penelitian dengan melihat nilai minimum 
nilai rata-rata (mean), dan standar deviasi. Analisis statistik deskriptif dapat dilihat pada Tabel 3. berikut.

Tabel 3. Analisis Statistik Deskriptif

\begin{tabular}{|c|c|c|c|c|c|}
\hline Variabel & $\mathrm{Ni}$ & Minimumi & Maximumi & Meani & $\begin{array}{l}\text { Std.i } \\
\text { Deviationi }\end{array}$ \\
\hline $\begin{array}{l}\text { Kinerja Lingkungan } \\
\left(\mathrm{X}_{1}\right)\end{array}$ & 72 & 1,00 & 4,00 & 3,0278 & 0,60450 \\
\hline $\begin{array}{l}\text { Umur Perusahaan } \\
\left(\mathrm{X}_{2}\right)\end{array}$ & 72 & 1,00 & 36,00 & 18,0000 & 10,28605 \\
\hline $\begin{array}{l}\text { Proporsi Dewan } \\
\text { Komisaris } \\
\text { Independen }\left(X_{3}\right)\end{array}$ & 72 & 0,30 & 83 & ,4297 & 0,12484 \\
\hline $\begin{array}{l}\text { Pengungkapan } \\
\text { Informasi } \\
\text { Lingkungan (Y) }\end{array}$ & 72 & 0,32 & ,82 & 5693, & 0,09125 \\
\hline
\end{tabular}

Berdasarkan hasil uji statistik deskriptif pada Tabel 3. diketahui bahwa jumlah sampel yang digunakan sebanyak 72 pengamatan yang diperoleh dari 24 perusahaan dengan periode 3 tahun. Statistik deskriptif yang ditunjukkan pada Tabel 3. adalah nilai minimum nilai maksimum rata-rata dan simpangan baku berdasarkan variabel yang digunakan dalam penelitian. Hasil uji statistik deskriptif menunjukkan nilai minimum sebesar 0,30 dan nilai maksimum sebesar 0,83 . Nilai standari deviasi sebesar 0,12484 lebih kecil dari nilai rata-rata sebesar 0,4297 memilik arti bahwa data tersebar normal dan tidak menimbulkan bias.

Berdasarkan hasil pengujian Kolmogorov-Smirnov nilaiiAsymp. Sigi (2tailed) dari hasil pengujian pada persamaan regresi linear berganda sebesar 0,067 lebih besar dari level of significant yaitu 5 persen $(0,05)$. Jadi dapat disimpulkan bahwa nila residual pada model regresi yang diuji sudah berdistribusi normal.

Berdasarkan hasil uji multikolinearitas menunjukkan variabel kinerja lingkungan memeroleh nilai tolerance sebesar 0,957 dan nilai VIF sebesar 1,044. Variabel umur perusahaan memeroleh nilai tolerance sebesar 0,968 dan nilai VIF sebesar 1,033. Variabel proporsi dewan komisaris independen memeroleh nilai tolerance sebesar 0,964 dan nilai VIF sebesar 1,037. Hasil nilai tolerance pada masing-masing variabel lebih besar dari $10 \%(0,1)$, demikian pula dengan nilai VIF masing-masing variabel yang lebih kecil dari 10. Hasil ini menunjukkan bahwa tidak terdapat korelasi antar variabel bebas pada persamaan regresi linieri berganda dengan variabel dependen pengungkapan informasi lingkungan sehingga persamaan bebas dari gejala multikolinearitas.

Berdasarkan hasil uji autokorelas menunjukkan bahwa besarnya nilai Aymp. iSig (2-tailed) pada uji Run Test sebesar 0,097. Nila tersebut akan dibandingkan dengan nilai signifikansi sebesar 0,05 ataui 5\%, dan dengan jumlah data sebanyak 72. Nilai Aymp. Sig (2-tailed) sebesar 0,097 yang lebih dari 0,05, maka dapat disimpulkan bahwa tidak terdapat autokorelas antar nilai residual dalam model regresi ini.

Berdasarkan hasil uji heteroskedastisitas memeroleh hasil nilai signifikansi Kinerja lingkungan (X1) sebesar 0,309, Umur perusahaan (X2) sebesar 0,536, dan Proporsi dewan komisaris independen (X3) sebesar 0,560. 
Hasil uji memeroleh nilai lebih besar dari $a=0.05$. Hal ini menunjukkan bahwa model regresi bebas dari gejala heteroskedastisitas.

Dari hasil analisis regresi linear berganda pada Tabel 4. dapat dibuat persamaan sebagai berikut:

Keterangan:

$$
Y=0,265+0,077 X 1-0,000 \times 2+0,175 X 3
$$

$\mathrm{Y} \quad=$ Pengungkapani Informasii Lingkungani

$\mathrm{X} 1 \quad=$ Kinerjai lingkungani

$\mathrm{X} 2=$ Umur perusahaani

$\mathrm{X} 3=$ Proporsi dewan komisaris independen

Tabel 4. Hasil Analisis Regresi Linear Berganda

\begin{tabular}{|c|c|c|c|c|c|c|}
\hline \multirow{2}{*}{\multicolumn{2}{|c|}{ Modell }} & \multicolumn{2}{|c|}{$\begin{array}{l}\text { Unstandardizedp } \\
\text { Coefficientsi }\end{array}$} & \multicolumn{3}{|c|}{$\begin{array}{l}\text { Standardizedi } \\
\text { Coefficientsi }\end{array}$} \\
\hline & & B & Std. Error & Betap & $\mathrm{T}$ & Sig. \\
\hline \multirow[t]{4}{*}{1} & (Constant)r & .265 & .054 & & 4.940 & .000 \\
\hline & $\begin{array}{l}\text { Kinerja } \\
\text { lingkungan }\left(X_{1}\right)\end{array}$ & .077 & .015 & .512 & 5.180 & .000 \\
\hline & $\begin{array}{l}\text { Umur } \\
\text { perusahaan }\left(X_{2}\right)\end{array}$ & .000 & .001 & -.014 & -0.141 & .888 \\
\hline & $\begin{array}{l}\text { Proporsi dewan } \\
\text { Komisaris } \\
\text { independen }\left(X_{3}\right)\end{array}$ & .175 & .068 & .251 & 2.552 & .013 \\
\hline
\end{tabular}

Sumber: Data Penelitian, 2019

Nilai konstanta sebesari 0,265. Hasil menunjukkan bahwa apabila nilai kinerja lingkungan, umur perusahaan dan proporsi dewan komisaris sama dengan nol maka besarnya Pengungkapan Informasi Lingkungan adalah 0,265 dengan asumsi variabeli lainnya konstan. Nilai koefisien $\beta 1=0,077$. Hasil ini menunjukkan bahwa jika kinerja lingkungan meningkat atau bertambah satu satuan maka akan meningkatkan pengungkapan informas lingkungan sebesar 0,077 dengan asumsi variabel lainnya konstan. Nilai koefisien $\beta 2=-0,000$. Hasil ini menunjukkan bahwa tidak pada pengaruh variabelitas umur perusahaan pada pengungkapan informasi lingkungan. Nilai koefisien $\beta 1=0,175$. Hasil ini menunjukkan bahwa jika proporsi dewan komisaris independen meningkat atau bertambah satu satuan, maka akan meningkatkan pengungkapan informasi lingkungan sebesar 0,175 dengan asumsi variabel lainnya konstan.

Berdasarkan hasil uji kelayakan model (uji F) sebesar 120,975 dan P value sebesar 0,000. Hasil ini lebihikecil dari a yang ditentukan yaitu 0,05. Hal ini mengindikasikan secara simultan Kinerja lingkungan (X1), Umur perusahaan (X2), dan Proporsi dewan komisaris independen (X3) berpengaruh signifikan pada Pengungkapan Informasi Lingkungan.

Berdasarkan hasil uji koefisien determinasi diperoleh besarnya adjusted R2 adalah sebesar 0,336. Ini berarti sebesar 33,6 persen variasi Pengungkapan Informasi Lingkungan secara signifikan dapat dipengaruhi oleh variabelitas Kinerja lingkungan (X1), Umur perusahaan (X2), dan Proporsi dewan komisaris independeni (X3), sedangkani sebesar 66,4 persen dijelaskan oleh faktor-faktor lain selain faktor-faktor dalam pelitian. 
Berdasarkan hasil perhitungan uji $\mathrm{t}$ diperoleh bahwa variabel $\mathrm{X} 1$ atau Kinerja lingkungan memiliki nilai koefisien regresi yang positif sebesar 0,077. Dibandingkan dengan taraf nyata $\alpha=0,050$, tingkat signifikansi lebih kecil sebesar 0,000. Hasil ini memiliki arti bahwa Kinerja lingkungan berpengaruh positif pada Pengungkapan Informasi Lingkungan yang berart Hipotesis 1 diterima. Variabel $\mathrm{X} 2$ atau Umur perusahaan memiliki nilail koefisien regresi sebesar 0,000. Dibandingkan dengan taraf nyata $\alpha=0,050$, tingkat signifikansi lebih besar sebesar 0,888. Hasil ini memiliki arti bahwa Umur perusahaan tidak berpengaruh pada Pengungkapan Informasi Lingkungan, yang berarti Hipotesis 2 ditolak. Variabel X3 atau Proporsi dewan komisaris independen memiliki nilai koefisien regresi yang positif sebesar 0,175 . Dibandingkan dengan taraf nyata $\alpha=$ 0,050, tingkat signifikansi lebih kecil sebesar 0,013. Hal ini menunjukkani bahwa Proporsi dewan komisaris independen berpengaruh positif pada Pengungkapani Informasi Lingkungan, yang berarti Hipotesis 3 diterima.

Hasil uji regresi linier berganda menunjukkan bahwa kinerja lingkungan secara statistik berpengaruh positif pada pengungkapan informasi lingkungan $\left(\mathrm{H}_{1}\right.$ diterima). Penelitiani ini sejalan dengan penelitian yang dilakukan oleh Fontana (2015), Putra \& Utami (2017) serta Purnama (2018) yang menyatakan terdapat hubungan yang positif antara kinerja lingkungan dan pengungkapan informasi lingkungan.

Hasil uji regresi linier berganda menunjukkan bahwa secara statistik umur perusahaan tidak berpengaruh pada pengungkapan informasi lingkungan $\left(\mathrm{H}_{2}\right.$ ditolak). Hal ini berarti lamanya suatu perusahaan tersebut berdiri dan terdaftar pada Bursa Efek Indonesia tidak menjamin ikualitas pengungkapan informasi lingkungan yang dilakukan oleh perusahaan. Hasil penelitian tidak mendukung penelitian Ciriyani \& Putra (2016) yang menyatakan bahwa umur perusahaan berpengaruh positif pada pengungkapan informasi lingkungan.

Hasil uji regresi linier berganda menunjukkan bahwa propors dewan komisaris independen secara statistik berpengaruh positif pada pengungkapan informasi lingkungan $\left(\mathrm{H}_{3}\right.$ diterima). Penelitian ini sejalan dengan penelitian yang dilakukani olehi Juniartha dan Dewi (2017) dan penelitian oleh Wardani dan Haryani (2018) membuktikan bahwa proporsi dewan komisaris independen berpengaruh positif pada pengungkapan informasi lingkungan.

\section{SIMPULAN}

Simpulan dalam penelitian ini dimana, kinerja lingkungan berpengaruh positif pada pengungkapan informasi lingkungan. Semakin tinggi kualitas kinerja lingkungan suatu perusahaan maka dorongan untuk mengungkapkan kepada investor dan stakeholder mengenai aktivitas lingkungan yang sudah dilakukan oleh perusahaan semakin tinggi sehingga memengaruh kualitas informasi yang diungkapkani dalami laporani tahunani iperusahaan. Tidak ditemukan adanyai hubungan antara umur perusahaan dengan pengungkapan informasi lingkungan. Proporsi dewan komisaris indepeden berpengaruh positif pada pengungkapan informasi lingkungan.

Saran bagi peneliti selanjutnya agar mempertimbangkan untuk memperluas sampel penelitian meliput seluruh perusahaan di Bursa Efek Indonesia selain sektor high profile dengan pengujian pengamatan yang lebih 
lama serta dapat pula menambahkan variabel-variabel lain yang memengaruhi pengungkapan informasi lingkungan. Investor sebaiknya mempertimbangkan variabel kinerja lingkungan dan proporsi dewan komisaris independen sebagai tambahan informasi mengenai keputusan investasi serta memperhatikan aspek lain khususnya aspek-aspek lingkungan dengan demikian sebagai investor tidak hanya terpaku pada ukuran-ukuran moneter. Perusahaan dengan aktivitas industr rawan lingkungan hendaknya mengikut PROPER dan memperhatikan serta mengungkapkan lebih rinci tiap item dalam pengungkapan informasi lingkungan yang sesuai berdasarkan standar dan indikator yang telah dikeluarkan Global Reporting Index (GRI) secara khusus melalui laporan keberlanjutan atau laporan tahunan.

\section{REFERENSI}

Ahada, M., Unggul, P., \& Murdayanti, Y. (2016). Pengaruh Environmental Performance dan Komposisi Dewan Komisaris terhadap Environmental Disclosure. Jurnal Ilmiah Wahana Akuntansi, 11(1), 125.

Al-Tuwaijri, Sulaeman A, et al. (2003). The relationship among Environmental Disclosure, Environmental Performance, and Economic Performance: A Simultaneous Equation Approach. Accounting Organization and Society, 29, . 447-471.

Amelia, \& Cahyati, A. D. (2015). Pengaruh Kinerja Keuangan, Kinerja Lingkungan, Size, dan Ukuran Dewan Komisaris terhadap CSR Disclosure. JRAK, 6(2), 64-79.

Anggraini, R. (2006). Pengungkapan Informasi Sosial Dan Faktor Faktor Yang Mempengaruhi Pengungkapan Informasi Sosial Dalam Laporan Keuangan Tahunan (Studi Empiris pada Perusahaan-Perusahaan yang Terdaftar Bursa Efek Jakarta). Simposium Nasional Akuntansi 9. Padang.

Aulia, F. Z., \& Agustina, L. (2015). Pengaruh Karakteristik Perusahaan, Kinerja Lingkungan dan Liputan Media terhadap Environmental Diasclosure. Accounting Analysis Journal, 4(3), 1-8.

Brown, Noel, \& Deegan, C. (1998). The Public Disclosure of Environmental Performance Information (A dual Test of Media Agenda Setting Theory and Legitimacy Theory). Accounting and Business Research, 29(1), 21-41.

Cho, C. H., \& Patten, D. M. (2007). The role of environmental disclosures as tools of legitimacy: A research note. Accounting, Organizations and Society, 32(7-8), 639-647. https:// doi.org/10.1016/j.aos.2006.09.009

Ciriyani, N., \& Putra, I. (2016). Pengaruh Ukuran Perusahaan, Profitabilitas, Dan Umur Perusahaan Pada Pengungkapan Informasi Lingkungan. EJurnal Akuntansi, 17(3), 2091-2119.

Clarkson, M., P., Yue Li, G. D. R., \& Vasvari., F. P. (2008). Revisiting The Relation Between Environmental Performance And Environmental Disclosure: An Empirical Analysis. Accounting, Organizations and Society, 33(4-5), 303-327. 
Dowling, J., \& Pfeffer, J. (1975). Organizational legitimacy: Social values and Organizational Behaviour. Pacific Social Review, 18(1), 122-136.

Emre Akbas, H. (2014). Company Characteristics and Environmental Disclosure: An Empirical Investigation on Companies Listed on Borsa Istanbul 100 Index. 145-164.

Fama, E. F., \& Jensen, M. C. (1983). Separation of Ownership and Control. Journal of Law and Economics, 26, 301-325.

Fontana, S. (2015). "Does Environmental Performance Affect Companies' Environmental Disclosure?". Reserch Paper, 19(3), 42-57.

Ghani, S. A., \& Rosdi, D. (2019). The Relationship between Environmental Performance and Corporate Governance towards Environmental Disclosure of Oil and Gas Companies Operating in Malaysia Upstream Projects. International Journal of Academic Research in Business and Social Sciences, 9(3), 460-475. https:/ / doi.org/10.6007/IJARBSS/v9-i3/5706

Ghozali, I., \& Chairi. (2016). Teori Akuntansi. Semarang: Badan Penerbit Universitas Diponegoro.

Hui, L. J. (2012). Board Monitoring, Management Contracting and Earnings Management: An Evidencefrom ASX Listed Companies. International. International of Economics and Finance, 4(12).

Ijma, H. N., \& Nina, Y. (2018). Pengaruh Ukuran Perusahaan, Profitabilitas Dan Porsi Kepemilikan Publik, Terhadap Environtmental Disclosure (Studi pada Perusahaan Logam dan Mineral Lainnya yang Terdaftar di Bursa Efek Indonesia). Katalogis, 6(4), 1-9.

Juhairiyah, Afifudin, \& Junaidi. (2018). Pengaruh Dewan Komisaris Terhadap Environmental Disclosure Pada Perusahaan Manufaktur Yang Listing Di Bei Tahun 2015-2017. E-JRA, 7(1). https:/ / doi.org/https://doi.org/10.1186/1476-4598-10-45

Juniartha, I. M., \& Dewi, R. R. (2017). Pengaruh proporsi komisaris independen, kinerja lingkungan, dan pertumbuhan perusahaan terhadap pengungkapan lingkungan.

Ningsih (2017), P. M. G. C. G. dan M. L. terhadap E. D. (2017). Prodi akuntansi fakultas ekonomi universitas negeri padang 2017.

O'Donovan, G. (2002). Environmental Disclosures in The Annual Report: Extending The Applicability and Predictive Power of Legitimacy Theory. Accounting, Auditing, and Accountability Journal, 15(3), 314371.

Orlitzky, M., Schmidt, F. L., \& Rynes, S. L. (2003). Corporate social and financial performance: A meta-analysis. In Organization Studies (Vol. 24). https:/ / doi.org/10.1177/0170840603024003910

Pertiwi, C. A. P., Malikah, A., \& Junaidi. (2018). Pengaruh Environmental Performance dan Environmental Disclosure terhadap Economic Performance (Studi Empiris pada Perusahaan Manufaktur Sektor Industri Dasar dan Kimia yang Terdaftar pada BEI pada Tahun 2012-2016). E-Jra, 07(01), 12-19.

Purnama, D. (2018). Analisis Kartakteristik Perusahaan dan Environmental Performance terhadap Environmental Disclosure. JRKA, 4(1), 1-14. 
Putra, B., \& Wirakusuma, M. (2015). Pengaruh Pengungkapan Corporate Social Rsesponsibility Pada Nilai Perusahaan Dengan Profitabilitas Sebagai Pemoderasi. E-Jurnal Akuntansi, 13(2), 461-475.

Putra, D., \& Utami, I. (2017). Pengaruh Environmental Performance Terhadap Environmental Disclosure dan Economic Performance (Studi Empiris pada Perusahaan Pertambangan yang Terdaftar Di BEI). Jurnal Akuntansi, 9(1), 1-11.

Putri, I. (2016). Sumber Daya Manusia, Good Corporate Governance, Dan Kinerja Perusahaan. Piramida, 11(1), 29-34.

Roberts, R. W. (1992). Determinants Of Corporate Social Responsibility Disclosure: An Aplication Of Stakeholder Theory". Accounting, Organisations and Society., 17(6), 595-612.

Sawaka, I. G. N. H., \& Putri, I. G. A. M. A. D. (2016). Analisis pengungkapan dan dampak penerapan. Analisis Pengungkapan Dan Dampak Penerapan Corporate Social Responsibilty Di Pt Bank Pembangunan Daerah Bali. 16, 837-864.

Sugiyono. (2017). Metode Penelitian Pendidikan Pendekatan Kuantitatif, Kualitatif, dan RED. Bandung: Alfabeta.

Uwuigbe, U., State, O., Egbide, B. C., Univeristy, C., Land, C., Ogun, O., \& Ayokunle, A. M. (2011). The Effect of Board Size and Board Composition on Firms Corporate Environmental Disclosure: A Study of Selected Firms in Nigeria The Effect of Board Size and Board Composition on Firms Corporate Environmental Disclosure: A Study of Selected Firms in. (October).

Wang, F., Yang, S., Reisner, A., \& Liu, N. (2019). Does green credit policy work in China? The correlation between green credit and corporate environmental information disclosure quality. Sustainability (Switzerland), 11(3). https:// doi.org/10.3390/su11030733

Wardani, D. K., \& Haryani, S. (2018). Akuntansi, P. S., Ekonomi, F., Sarjanawiyata, U., \& Yogyakarta, T Dampak Corporate Governance Terhadap. 67-82.

Yasa, G. W. (2017). E-Jurnal Akuntansi Universitas Udayana DISCLOSURE Ida Ayu Putu Oki Yacintya Dewi 1 Fakultas Ekonomi dan Bisnis Universitas Udayana ( Unud ), Bali, Indonesia e-mail: okiyacintya@gmail.com / 0878126013312 Fakultas Ekonomi dan Bisnis Universitas Udayana (. 20, 2362-2391.

Yuniarta, Gede Adi, D. (2019). Pengaruh Mekanisme Good Corporate Governance, Profitabilitas, dan Kinerja Lingkungan Terhadap Environmental Disclosure. E-Jurnal S1 Ak Universitas Pendidikan Ganesha Jurusan Akuntansi Program S1 (Vol: 10 No: 1 Tahun 2019), 10.

Yuniasih, N. W., \& Wirakusuma, G. M. (2008). Pengaruh kinerja keuangan terhadap nilai perusahaan dengan pengungkapan. Jurnal Akuntansi, $1-10$. 